\title{
Aplikasi Berbasis Mobile untuk Diabetisi dalam Menunjang Ibadah Puasa, Haji dan Umroh Kerja Sama Persadia Unit RSI Sultan Agung
}

\author{
${ }^{1}$ Sri Mulyono*, ${ }^{2}$ Nur Anna Chalimah Sa'dyah, ${ }^{2}$ Minidian Fasitasari \\ ${ }^{1}$ Teknik Informatika, Fakultas Teknologi Industri, Universitas Islam Sultan Agung, Semarang, Indonesia \\ ${ }^{2}$ Fakultas Kedokteran, Universitas Islam Sultan Agung, Semarang, Indonesia \\ *Corresponding Author: \\ E-mail: sri.m@unissula.ac.id
}
Received:
Revised:
1 January 2021
15 April 2021
Accepted:
15 May 2021
Published:
31 May 2021

\begin{abstract}
Abstrak
Dari data Kementerian Kesehatan dari Sampel Registration Survey 2014 menyebutkan bahwa diabetes telah menjadi penyebab kematian terbesar nomor 3 di Indonesia, dengan presentase sebesar $6,7 \%$, setelah stroke $(21,1 \%)$ dan penyakit jantung koroner $(12,9 \%)$, Berdasarkan data Riskesdas 2013 (Kemenkes RI, 2013), 90\% dari total kasus diabetes merupakan diabetes tipe 2, yang umumnya terjadi pada orang dewasa. Namun beberapa tahun terakhir makin banyak ditemukan pada usia dewasa muda kurang dari 30 tahun bahkan pada anak-anak dan remaja. Indonesia merupakan negara muslim terbesar di dunia. Jumlah penduduk Indonesia 258 juta $87,2 \%$ adalah warga muslim. Sebagai warga muslim disyariatkan untuk melaksanakan berbagai ibadah antara lain ibadah puasa di bulan ramadan, haji dan umroh. Pada saat puasa pasien diabetes tidak makan selama siang hari yang berpeluang menimbulkan kecenderungan makan berlebih pada malam hari. Hal ini berpotensi menyebabkan pasien 5 kali lebih berisiko mengalami hiperglikemia dan sebanyak 7 kali lebih berisiko mengalami hipoglikemia. Kegiatan edukasi program aplikasi berbasis mobile untuk diabetesi sebagai bekal dalam menjalankan ibadah puasa haji dan umroh telah dilaksanakan dengan yang diikuti oleh 348 peserta dengan berbagai unsur peserta antara lain dokter, mahasiswa kesehatan, perawat dan ibu rumah tangga. Aplikasi juga telah didistribusikan di google playstore sehingga masyarakat luas akan lebih mudah mengunduh, memasang dan memakai aplikasi tersebut dimana saja, kapan saja dengan melalui koneksi internet.
\end{abstract}

Kata kunci: diabetes; haji; puasa ramadan; umroh.

\begin{abstract}
Data from the Ministry of Health from the 2014 Sample Registration Survey states that diabetes has become the 3rd largest cause of death in Indonesia, with a percentage of $6.7 \%$, after stroke (21.1\%) and coronary heart disease (12.9\%). Data from Riskesdas 2013 (Kemenkes RI, 2013), 90\% of total diabetes cases are type 2 diabetes, which generally occurs in adults. However, in recent years, it is increasingly found in adults less than 30 years, even in children and adolescents. Indonesia is the largest Muslim country in the world. The total population of Indonesia 258 million 87.2\% are Muslims. As Muslim citizens, they are obliged to carry out various acts of worship, including fasting in the month of Ramadan, Hajj and Umrah. During fasting, diabetic patients do not eat during the day which may lead to a tendency to overeat at night. This puts the patient 5 times more likely to develop hyperglycemia and 7 times more likely to develop hypoglycemia. Educational activities for mobile-based application programs for diabetes as a provision for carrying out the Hajj and Umrah fasting services have been carried out by 348 participants with various participants including doctors, health students, nurses and housewives. Applications have also been
\end{abstract}


distributed on the Google Play Store so that the wider community will find it easier to download, install and use the application anywhere, anytime via an internet connection.

Keywords: diabetes; hajj; fasting ramadan; umrah

\section{PENDAHULUAN}

Data dari International Diabetes Federation (IDF) Atlas tahun 2017 menunjukkan bahwa Indonesia saat ini menduduki peringkat ke-6 dunia dengan jumlah penderita diabetes (diabetesi) terbesar, yaitu sebanyak 10,3 juta jiwa. Hasil Riset Kesehatan Dasar (Riskesdas) Tahun 2018 (Kemenkes RI, 2018) menunjukkan bahwa prevalensi penyandang diabetes naik mejadi 8,5\%, dari 6,9\% (Kemenkes RI, 2013). Data milik Kementerian Kesehatan dari Sample Registration Survey 2014 juga menyebutkan bahwa diabetes telah menjadi penyebab kematian terbesar nomor 3 di Indonesia, dengan presentase sebesar $6,7 \%$, setelah stroke $(21,1 \%)$ dan penyakit jantung koroner (12,9\%), Berdasarkan data Riskesdas 2013 (Kemenkes RI, 2013), 90\% dari total kasus diabetes merupakan diabetes tipe 2, yang umumnya terjadi pada orang dewasa. Namun beberapa tahun terakhir makin banyak ditemukan pada usia dewasa muda kurang dari 30 tahun bahkan pada anak-anak dan remaja.

Indonesia merupakan negara muslim terbesar di dunia. Jumlah penduduk Indonesia 258 juta $87,2 \%$ adalah warga muslim. Sebagai warga muslim disyariatkan untuk melaksanakan berbagai ibadah antara lain ibadah puasa di bulan ramadan, ibadah haji dan ibadah umroh. Pada saat puasa pasien diabetes tidak makan selama siang hari yang berpeluang menimbulkan kecenderungan makan berlebih pada malam hari. Hal ini berpotensi menyebabkan pasien 5 kali lebih berisiko mengalami hiperglikemia dan sebanyak 7 kali lebih berisiko mengalami hipoglikemia (Perkeni, 2015). Pada kegiatan pengabdian masyarakat ini dilaksanakan edukasi program aplikasi berbasis mobile untuk diabetisi khususnya pada Persadia unit RSI Sultan Agung Semarang sebagai bekal dalam menjalankan ibadah puasa haji dan umroh sehingga program edukasi dan penatalaksanaan dapat dilaksanakan dimana saja kapan saja.

Persadia (Persatuan Diabetes Indonesia) merupakan organisasi sosial yang mandiri. Pada awal berdirinya diprakarsai oleh para dokter ahli endokrin. Anggota dari Persadia meliputi dokter, tenaga profesional lain (perawat, ahli gizi), penderita diabetes, keluarga penderita serta mereka yang berminat. Sedangkan tujuan dari Persadia antara lain meningkatkan kesejahteraan penderita diabetes, menghimpun para penderita diabetes, dokter, petugas kesehatan yang lain, simpatisan, dan tenaga profesional lain yang terkait pelayanan diabetes untuk bekerja sama meningkatkan mutu pelayanan bagi para diabetisi, serta mewujudkan penderita diabetes yang mandiri. Pengurus Besar Persadia saat ini bertempat di Jakarta dan telah memiliki anggota yang tersebar di 11 wilayah, 94 cabang dan 172 unit/klub Persadia di seluruh Indonesia (RS Panti Wilasa, 2016). Persadia Unit RSI Sultan Agung yang merupakan salah satu bagian dari Persadia telah menyelenggarakan berbagai kegiatan antara lain penyuluhan atau edukasi. Selain itu senam diabetes juga telah dilakukan tiap hari Jum'at, kegiatan lainnya serta adalah kegiatan gathering/ wisata. Dampak kegiatan-kegiatan tersebut anggota dapat senantiasa menjaga kondisi kesehatan, saling berbagi dan memotivasi serta menambah pengetahuan tentang diabetes. Foto kegiatan senam diabetes Persadia unit RSI Sultan Agung ditunjukkan seperti pada Gambarl diikuti oleh dokter, perawat, pasien atau pemerhati diabetes (RSISA, 2015).

Edukasi diabetes sejak dini di keluarga, baik ayah, ibu, maupun anak, sangat penting untuk melindungi keluarga Indonesia dari diabetes. Selain perlindungan sebagai usaha preventif, pengelolaan berbagai hal bagi penderita diabetes (diabetisi) seperti pola makan, gaya hidup sangat penting untuk menjaga kestabilan gula darah diabetisi sehingga tidak menyebabkan dampak yang lebih buruk. 
Meskipun kegiatan-kegiatan telah banyak dilakukan tapi masih perlu terus dilakukan kegiatan positif lainnya yang dapat mendukung tujuan dari organisasi ini, karena banyaknya penderita diabetes, meningkatnya pertumbuhan penderita diabetes, rasio antara tenaga medis dengan diabetisi masih kecil, edukasi masih perlu dilakukan secara terus menerus bagi diabetisi, keluarga diabetisi maupun masyarakat pada umumnya. Solusi yang ditawarkan saat ini berupa aplikasi mobile karena diharapkan dapat meningkatkan komunikasi dalam memonitor kondisi gula darah pasien. Dari data penderita diabetes ada 30,2 \% yang tidak rutin berobat ke fasilitas layanan kesehatan, yang berpotensi menyebabkan gula darah tidak terkendali (Kemenkes RI, 2018).

Informasi lain terkait dengan Persadia unit RSI Sultan Agung Semarang dapat dilihat pada website (RSISA, 2015).

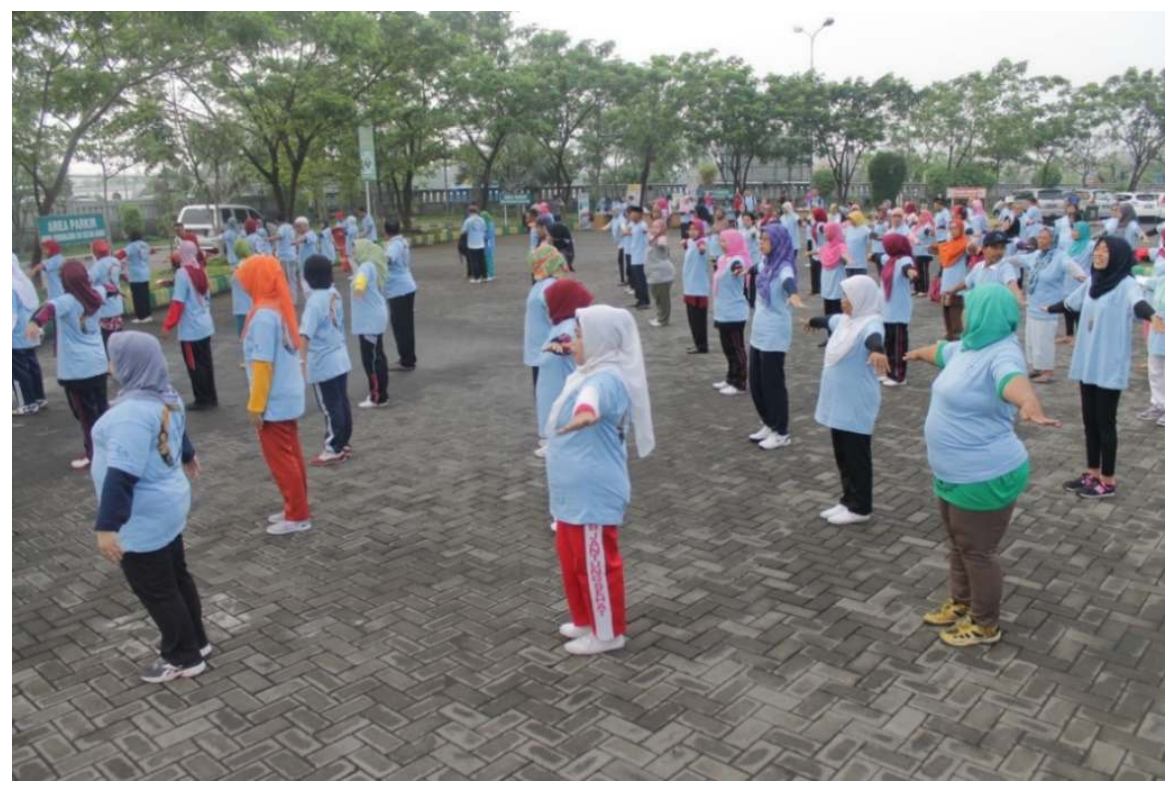

Gambar 1. Senam Diabetes Persadia Unit RSI Sultan Agung (RSISA, 2015)

\section{METODE}

Metode pelaksanaan kegiatan pengabdian masyarakat yang digunakan sebagai memberikan solusi bagi mitra dalam hal ini Persadia Unit RSI Sultan Agung dibagi menjadi beberapa tahap. Tahapan-tahapan tersebut seperti ditunjukkan pada Gambar 2. 


\section{a. Survei Awal}

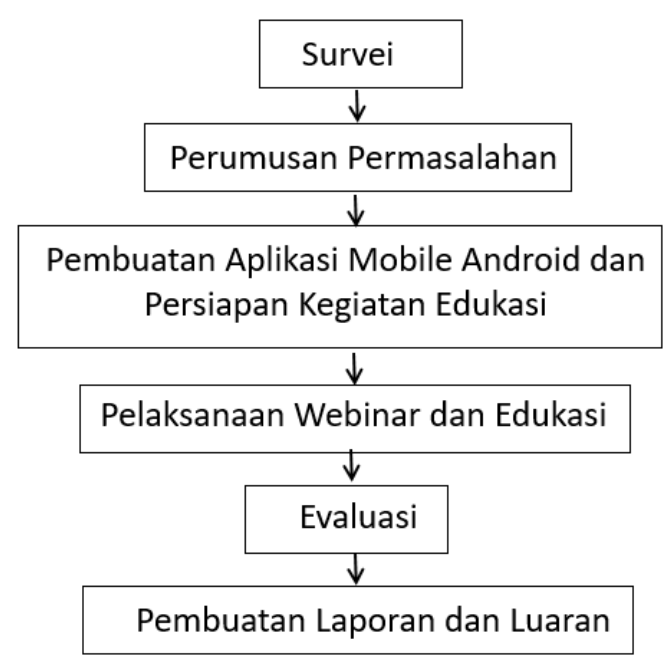

Kegiatan ini digunakan untuk mengetahui beberapa permasalahan yang dihadapi mitra, kondisi mitra secara umum serta kegiatan-kegiatan yang sudah dilaksanakan beserta evaluasinya. Beberapa permasalahan yang mengemuka antara lain: minimnya pengetahuan mengenai diabetes, rendahnya kesadaran masyarakat terutama penderita untuk secara rutin mengontrol kadar gula darah, kurangnya media informasi dan komunikasi antara diabetesi dan tenaga kesehatan. Lokasi mitra (Persadia) berada di lingkungan RSI Sultan Agung yang juga masih satu area dengan Universitas Islam Sultan Agung (Unissula). Pada gambar 3. Menunjukkan salah satu kegiatan Persadia unit RSI Sultan Agung berupa wisata edukasi yang dilakukan di Kampung Rawa Ambarawa dan Banaran, saat tim ahli diabetes memberikan edukasi ke salah satu peserta (RSISA, 2015).

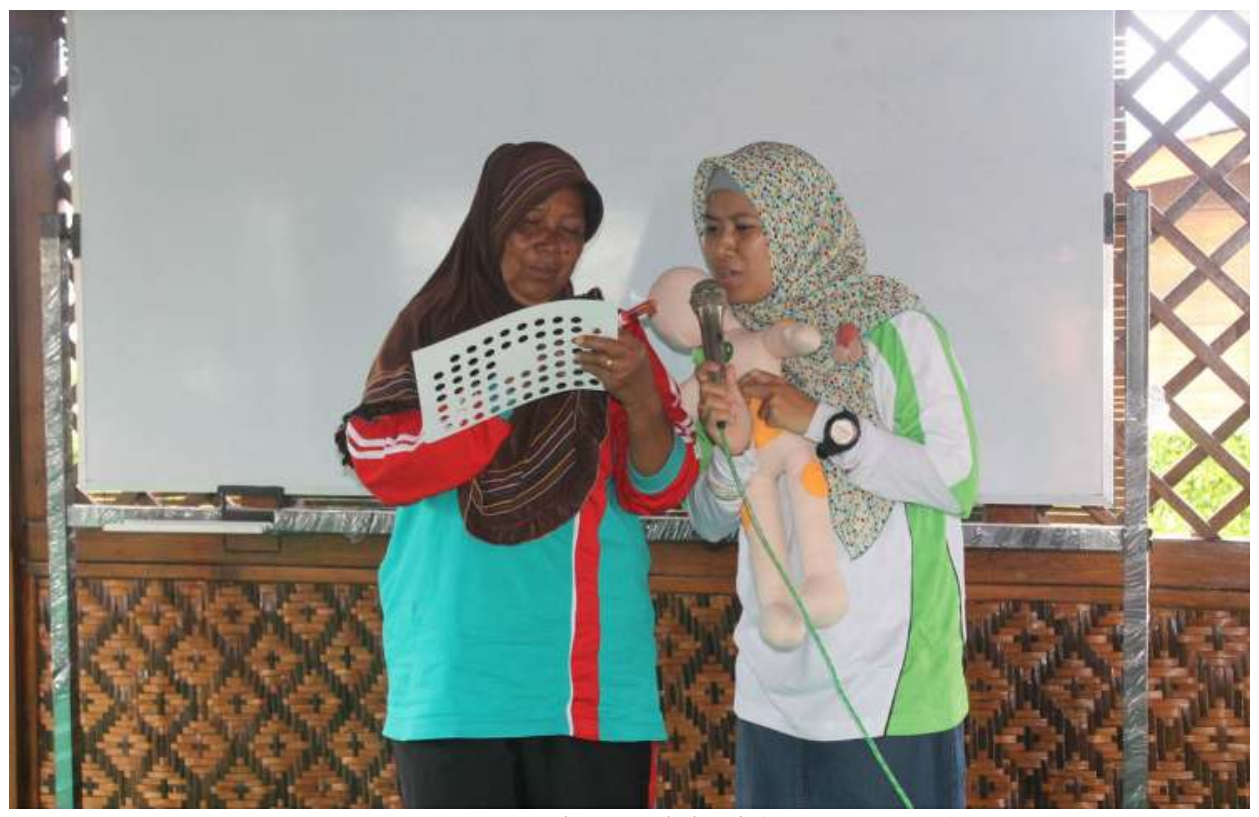

Gambar 3. Wisata Edukasi (RSISA, 2015) 
b. Perumusan Permasalahan

Pada kegiatan ini dilakukan diskusi untuk membahas berbagai permasalahan mitra serta merumuskannya, selain itu dilakukan berbagai persiapan pelaksanaan serta pembagian tugas. Pada bagian ini dirumuskan perlunya dibuat media edukasi dan komunikasi bagi diabetesi. Media edukasi dan komunikasi yang perlu dibuat adalah aplikasi mobile berbasis android.

c. Pembuatan Aplikasi Mobile dan Persiapan Kegiatan Edukasi

Pembuatan aplikasi dibuat berdasarkan perumusan masalah. Pembuatan Aplikasi mobile dilakukan dengan metode prototipe dengan tahapan (Purnomo, 2017) seperti ditunjukkan pada gambar 4.

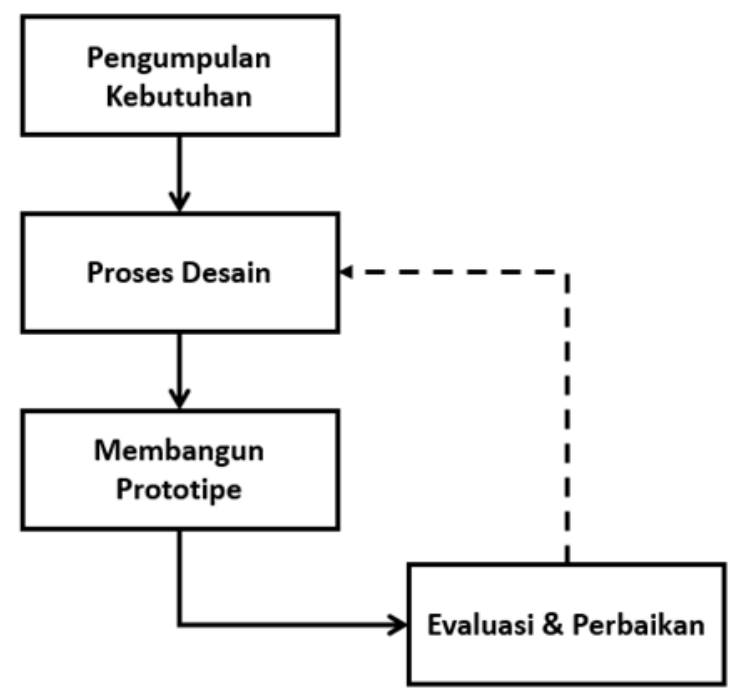

Gambar 4. Diagram alir prototipe.

Proses berikutnya adalah desain atau perancangan, meliputi desain arsitektur sistem, desain usecase dan desain GUI (Graphical User Interface) atau antar muka. Desain arsitektur sistem ditunjukkan seperti pada gambar 5.

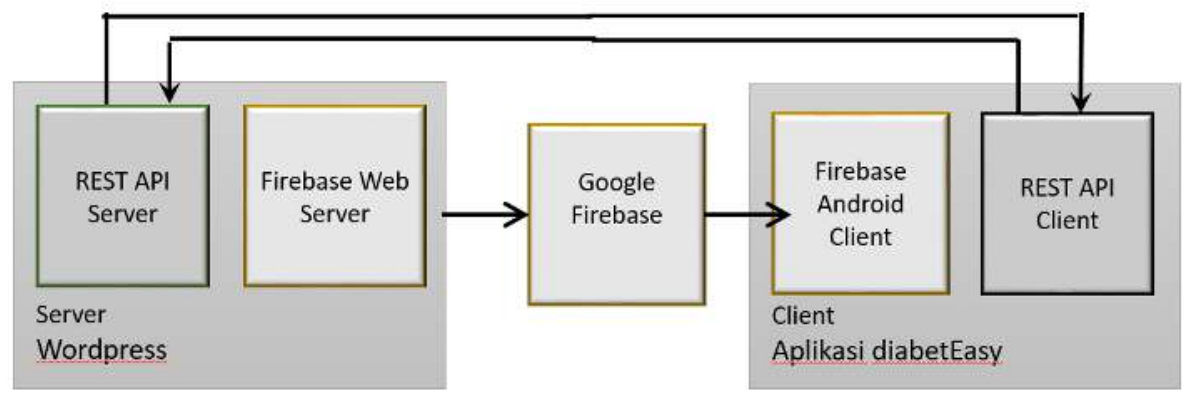

Gambar 5. Desain arsitektur sistem.

Pada Gambar 5 tersebut ditunjukkan bahwa pada bagian server ada layanan REST API dan layanan Firebase web serta layanan wordpress. Sedangkan pada sisi client (perangkat android) ada layanan REST API client dan Firebase Android client serta aplikasi diabetEasy. Bila ada permintaan informasi dari client melalui REST API maka server akan memberikan informasi ke client melalui REST API server. Bila pada wordpress ada pembaruan data baru, informasi tersebut dapat diatur untuk dapat dikirimkan berupa pesan ke client melalui Google Firebase. 
Pada diagram use case ditunjukkan seperti pada gambar 6 terdapat dua aktor yaitu admin dan pengguna. Pada admin dapat mengatur kategori, mengatur artikel, menerbitkan notifikasi dan memberikan komentar pada artikel. Sedangkan pada pengguna dapat melakukan pencarian artikel, melihat daftar artikel, mengirimkan pesan, membagikan aplikasi, memberikan rating penilaian, login ke sistem, memberikan favorit artikel (dengan login) dan melakukan registrasi (dengan login).

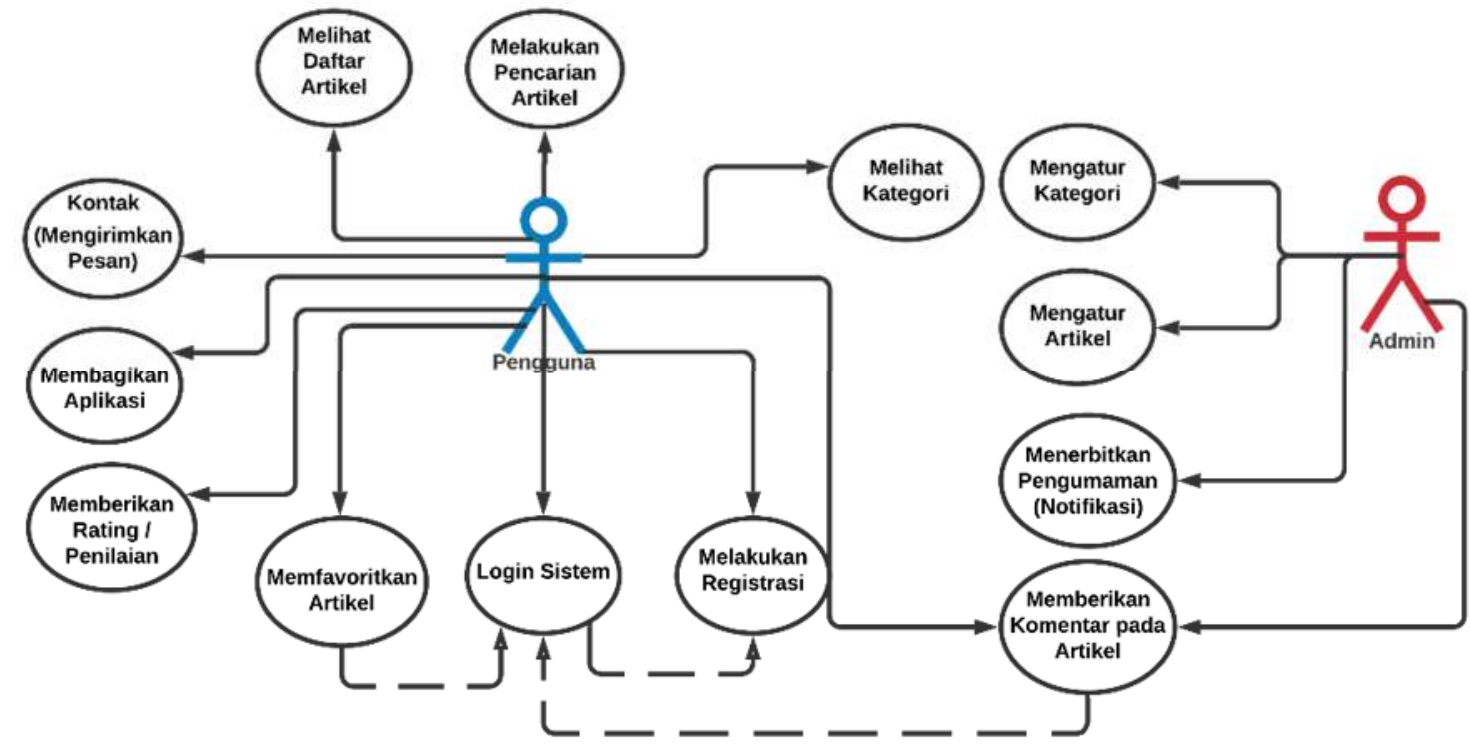

Gambar 6. Diagram use case.

Sedangkan rancangan GUI ditunjukkan seperti pada Gambar 7. yang terdiri dari splashscreen, home, kategori dan menu. Pada splashscreen ditampilkan logo, pada home ditampilkan informasi terbaru, pada kategori ditampilkan kategori sesuai dengan topik yaitu, mengenal diabetes, haji \& umroh, puasa, nutrisi, informasi dan kegiatan. Serta informasi tambahan mengenai covid-19

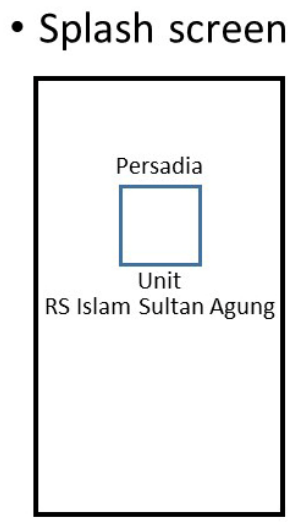

- Home

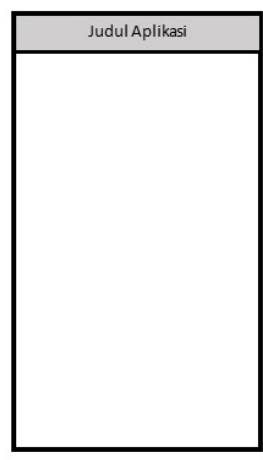

- Kategori

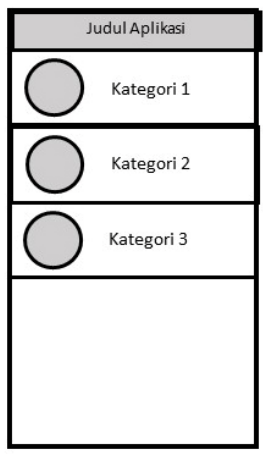

- Menu

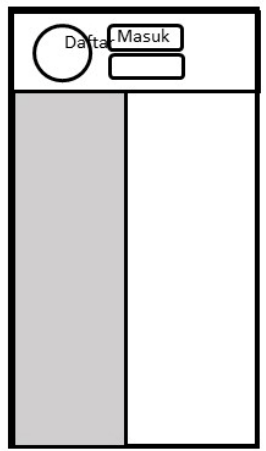

Gambar 7. Desain Graphical User Interface (GUI)

Persiapan kegiatan edukasi dan sosialisasi aplikasi mobile berbasis android dilakukan beberapa hal antara lain, pembuatan poster dan koordinasi dengan tim pelaksana webinar. 
Kegiatan persiapan dilakukan hingga aplikasi selesai dan sudah diunggah di play store, supaya saat acara webinar dan edukasi dapat dipraktekkan secara langsung oleh pengguna.

\section{d. Pelaksanaan Webinar dan Edukasi}

Kegiatan webinar dan edukasi ini meliputi webinar dengan topik yang berkaitan dengan tema pengabdian masyarakat, sosialisasi dan edukasi aplikasi mobile berbasis android untuk diabetisi sebagai panduan untuk membantu selama menjalankan ibadah puasa, ibadah haji atau umroh. Pelaksanan acara ini sekaligus dilakukan saat pertemuan Persadia unit RSI Sultan Agung Semarang.

\section{e. Evaluasi}

Kegiatan ini digunakan untuk mengevaluasi hasil pelaksanaan kegiatan pengabdian masyarakat bagaimana pengaruhnya terhadap mitra.

\section{f. Pembuatan Laporan dan Luaran}

Berupa laporan pelaksanaan kegiatan dengan dilampiri foto-foto dokumentasi kegiatan, daftar hadir peserta, liputan media masa serta aplikasi mobile untuk diabetisi yang sudah diunggah di playstore..

\section{HASIL DAN PEMBAHASAN}

Materi kegiatan inti adalah acara sosialisasi dan edukasi penggunaan aplikasi mobile untuk diabetesi yang diadakan tanggal 30 Agustus 2020 jam 09.00 sampai dengan jam 11.00. Karena masa pandemi maka acara sosialisassi dan edukasi dilaksanakan secara daring dengan webinar melalui zoom dan disiarkan secara live melalui Youtube (RSISA TV, 2020). Acara webinar dengan tema "Cara Mudah Pemantauan Mandiri Diabetisi Saat berpuasa, Haji/ Umroh menggunakan Aplikasi Android diabetEasy" (diabetEasy, 2020), dibagi dalam tiga bagian yaitu:

1. Pemantauan mandiri oleh diabetisi saat berpuasa, haji/ umroh dan saat pandemi, disampaikan oleh dr. Nur Anna Chalimah Sa'dyah, SpPD, K-EMD, FINASIM

2. Penyesuaian nutrisi untuk diabetisi saat puasa, haji/ umroh, disampaikan oleh dr. Minidian Fasitasari, M.Sc, SpGK

3. Diabeteasy aplikasi berbasis android untuk diabetisi, disampaikan oleh Ir. Sri Mulyono, M.Eng

Acara webinar yang dilangsungkan secara daring melalui Zoom dan Youtube diperlihatkan seperti pada gambar 8 . 


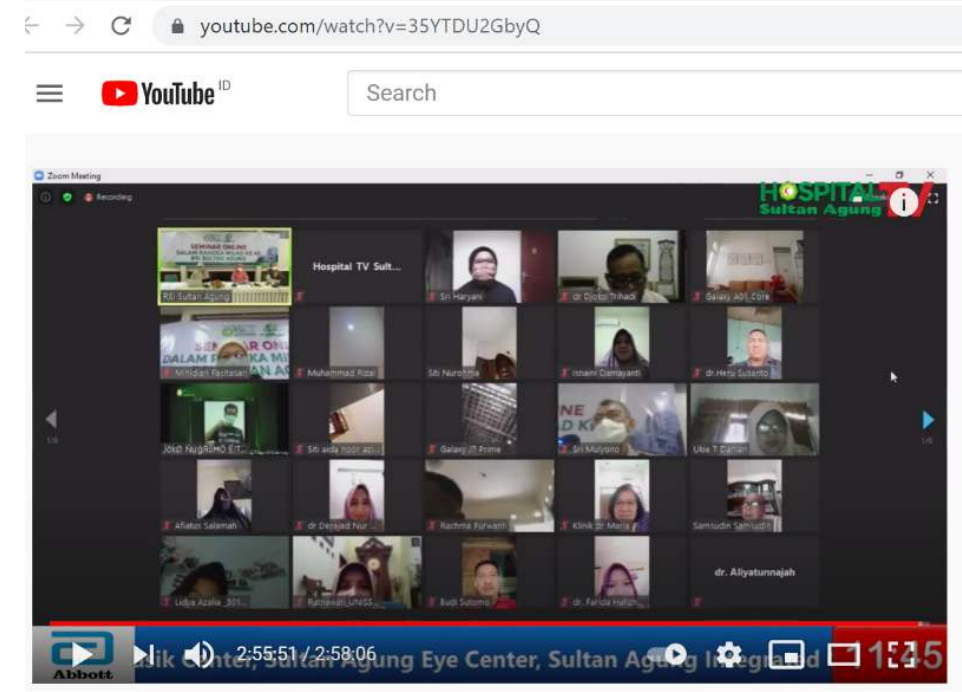

\& $\square * \equiv$

Q \) E \#

Gambar 8. Webinar Edukasi dan Sosialisas Melalui Zoom

Kegiatan tersebut juga diliput media online seperti di tunjukkan pada gambar 9 tentang aplikasi diabetEasy yang digunakan sebagai media edukasi dan komunikasi diabetesi (Fataip, 2020).

Peserta yang ikut terdiri berbagai kelompok profesi masyarakat dengan total peserta 384 orang. Kelompok kategori peserta dapat dilihat seperti ditunjukkan pada gambar 10. Peserta dari kategori dokter sebesar 33\%, dari koas dan perawat sebesar 24\% serta mahasiswa kesehatan sebesar 20\% mempunyai potensi positif yang dapat berperan sebagai edukator di lingkungan masing-masing. Dari diskusi yang sudah dilakukan rata-rata peserta menyatakan aplikasi sudah baik dari segi navigasi maupun konten mudah dipahami, beberapa peserta yang lain terutama dari kelompok dokter ingin agar aplikasi mobile dapat dikembangkan untuk perangkat berbasis IOS.

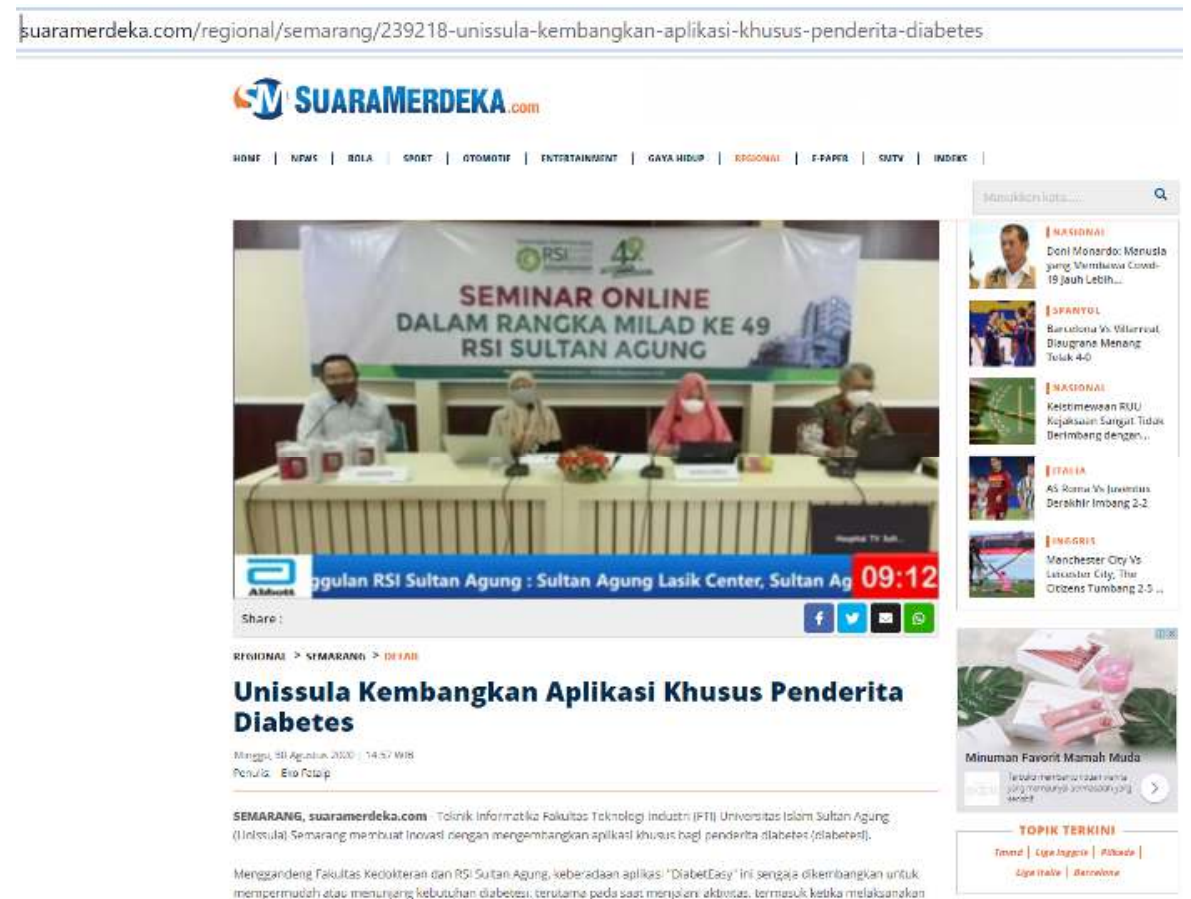

Gambar 9. Media online Suara Merdeka aplikasi DiabeteEasy (Fataip, 2020) 


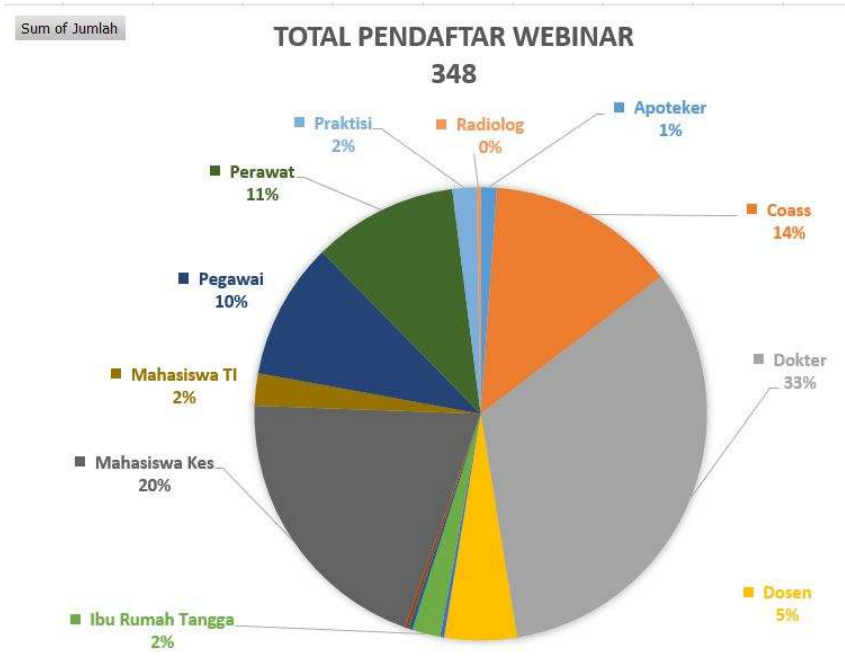

Gambar 10. Kelompok kategori peserta

Purwarupa/ prototype berupa aplikasi mobile berbasis android diabetEasy yang sudah diunggah di play store (diabetEasy, 2020). Aplikasi di playstore ditunjukkan seperti pada gambar 11. Purwarupa aplikasi ini merupakan versi 1.0 dengan ukuran file sekitar $10.0 \mathrm{M}$. Aplikasi ini membutuhkan versi android 5.0 ke atas, instalasi dengan ijin akses pengguna (user permissions) sebagai berikut:

- Kamera (mengambil gambar dan video).

- Foto / Media / File (membaca konten penyimpanan USB, mengubah atau menghapus konten penyimpanan USB).

- Penyimpanan (membaca konten penyimpanan USB mengubah atau menghapus konten penyimpanan USB).

- Lokasi (perkiraan lokasi (berbasis jaringan), lokasi yang tepat (GPS dan berbasis jaringan).

- Lain (menerima data dari Internet, melihat koneksi jaringan akses jaringan penuh, mencegah perangkat dari tidur (sleep condition).

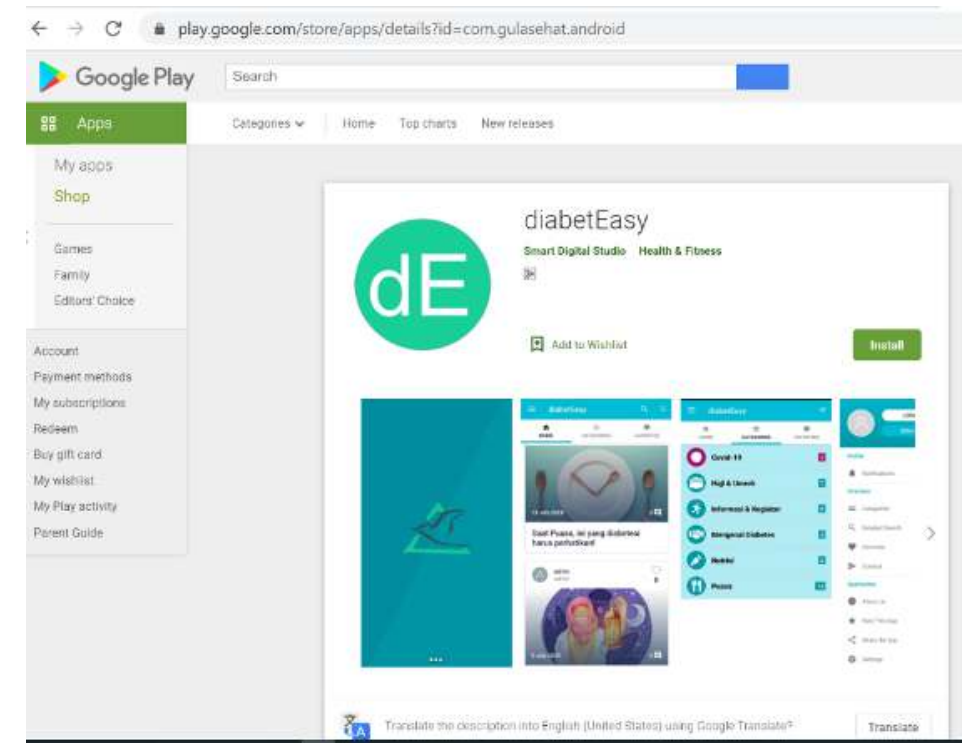

Gambar 11. Purwarupa/ prototype aplikasi diabetEasy di PlayStore. 

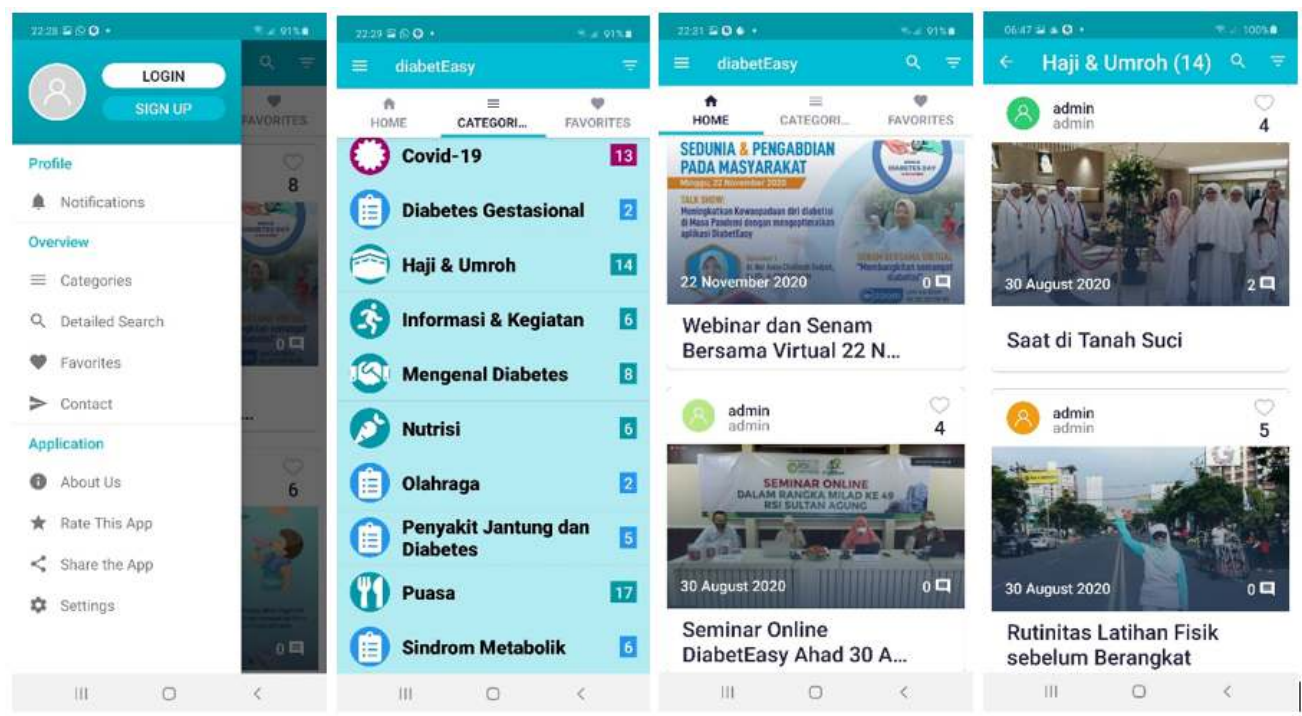

Webinar dan Senam Bersama Virtual $22 \mathrm{~N}$...

Saat di Tanah Suci

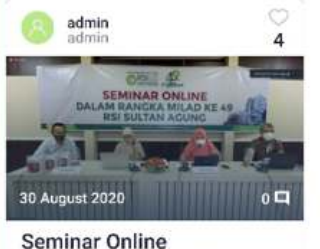

Seminar Online

DiabetEasy Ahad $30 \mathrm{~A}$...

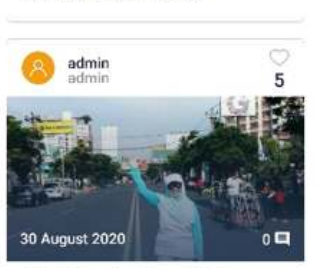

Rutinitas Latihan Fisik sebelum Berangkat

Gambar 12. Aplikasi diabetEasy setelah Dipasang di Smartphone Android.

Gambar 12 menunjukkan aplikasi diabetEasy yang sudah dipasang di smartphone android. Seperti desain Graphical User Interface (GUI) yang sudah dibuat, saat pertama aplikasi dijalankan akan menampilkan splashcreen yang akan menampilkan logo Persadia selama 3 detik, kemudian masuk ke menu utama. Pada menu kategori ditampilkan beberapa kategori antara lain mengenal diabetes, haji dan umroh, puasa dan nutrisi. Kategori dapat ditambahkan untuk pengembangan ke depan. Aplikasi juga dilengkapi menu drawer navigation untuk memudahkan pengguna. Selain itu pengguna juga dapat memberikan like dan komentar pada artikel yang ada pada aplikasi seperti ditunjukkan pada gambar 13. Hingga saat ini aplikasi sudah diunduh dan dipasang oleh 158 pengguna seperti ditunjukkan pada gambar 14.

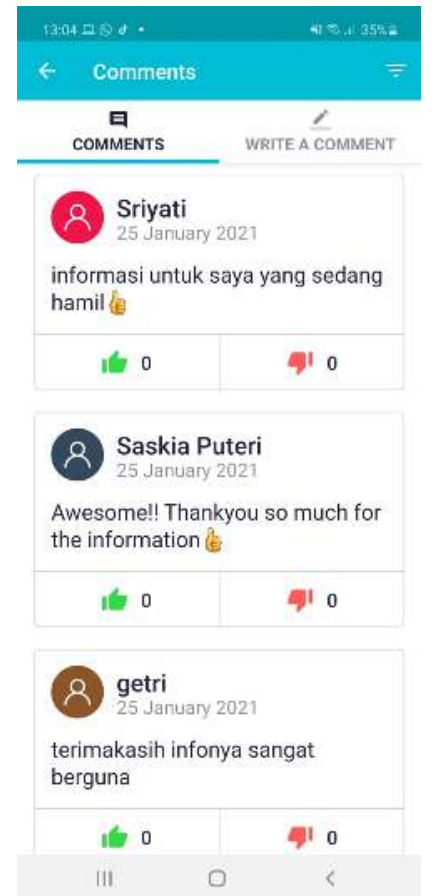

Gambar 13. Like dan Komentar

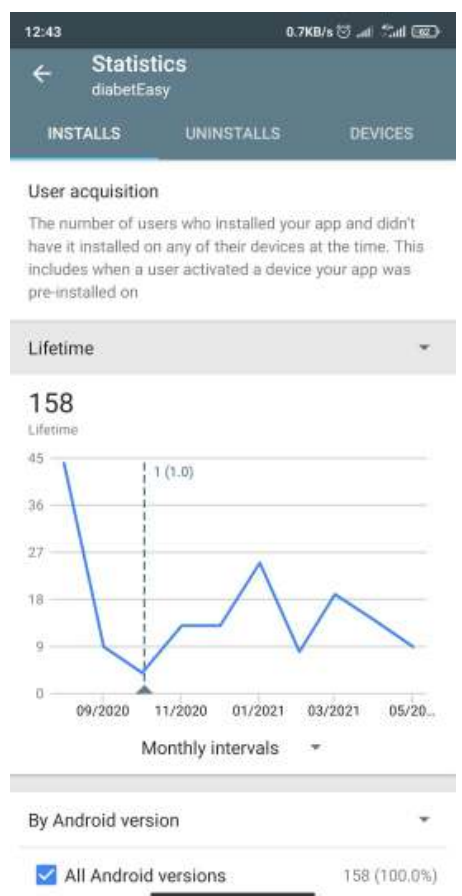

Gambar 14. Jumlah Pengguna 


\section{KESIMPULAN}

Dari kegiatan pengabdian kepada masyarakat yang dilaksanakan di Persadia unit RSI Sultan Agung Semarang dapat diberikan kesimpulan bahwa (1) Kegiatan edukasi program aplikasi berbasis mobile untuk diabetesi sebagai bekal dalam menjalankan ibadah puasa haji dan umroh telah dilaksanakan dengan yang diikuti oleh 348 peserta dengan berbagai unsur peserta antara lain dokter, mahasiswa kesehatan, perawat dan ibu rumah tangga. Dengan adanya webinar edukasi peserta dapat mengunduh dan memasang aplikasi diabetEasy dan dapat memanfaatkan fitur-fitur yang ada; (2) Aplikasi android berbasis mobile untuk diabetesi dalam menjalankan ibadah puasa haji dan umroh telah didistribusikan di google play store sehingga masyarakat luas akan lebih mudah mengunduh, memasang di perangkat smartphone android dan memakai aplikasi tersebut dimana saja, kapan saja dengan koneksi internet sebagai sarana informasi komunitas Persadia unit RSI Sultan Agung. Saat ini aplikasi sudah diunduh dan dipasang oleh 158 pengguna.

\section{UCAPAN TERIMA KASIH}

Ucapan terima kasih kepada berbagai pihak yang telah mendukung terselenggaranya kegiatan pengabdian kepada masyarakat ini: Lembaga Penelitian dan Pengabdian Masyarakat (LPPM) Universitas Islam Sultan Agung, Persatuan Diabetes Indonesia (Persadia) unit RSI Sultan Agung Semarang sebagai mitra dengan komunitasnya
DAFTAR PUSTAKA
diabetEasy. (2020). diabetEasy Aplikasi untuk Penderita/ Penyandang Diabetes. Retrieved from https://play.google.com/store/apps/details?id=com.gulasehat.android

Fataip, E. (2020). Kontributor Media Online Suaramerdeka.com. Retrieved from suaramerdeka.com: https:/www.suaramerdeka.com/regional/semarang/239218unissula-kembangkan-aplikasi-khusus-penderita-diabetes

Kemenkes RI. (2013). Laporan Nasinal Riset Kesehatan Dasar (RISKESDAS). Lembaga Penerbit Badan Penelitian dan Pengembangan Kesehatan.

Kemenkes RI. (2013). Riset Kesehatan Dasar (RISKESDAS). Badan Penelitian dan Pengembangan Kesehatan, Kemenkes RI.

Kemenkes RI. (2018). Laporan Nasinal Riset Kesehatan Dasar (RISKESDAS) . Lembaga Penerbit Badan Penelitian dan Pengembangan Kesehatan.

Kemenkes RI. (2018). Laporan Propinsi Jawa Tengah Riset Kesehatan Dasar (RISKESDAS). Lembaga Penerbit Badan Penelitian dan Pengembangan Kesehatan.

Perkeni. (2015). Panduan Penatalaksanaan DM Tipe 2 pada Individu Dewasa di Bulan Ramadhan. In Perkeni. Perkeni.

Perkeni. (2019). Pedoman Pemantauan Glukosa Darah Mandiri. PB PERKENI.

Perkeni. (2019). Pedoman Pengelolaan dan Pencegahan Diabetes Melitus Tipe 2 Dewasa di Indonesia. PB PERKENI. 
Purnomo, D. (2017, Agustus). Model Prototyping Pada Pengembangan. Jurnal Informatika Merdeka Pasuruan, Vol.2 No.2, 54-61.

RS Panti Wilasa. (2016). https://majalahkasih.pantiwilasa.com/. Retrieved from majalahkasih.pantiwilasa.com/detailpost/lebih-akrab-denganpersadia\#: :text=PERSADIA\%20mempunyai\%20wakil\%20ditiap\%20unit,klub\% 20Persadia\%20di\%20seluruh\%20Indonesia.

RSISA. (2015). Persatuan Diabetes Indonesia (Persadia) RSI Sultan Agung. Retrieved from https://rsisultanagung.co.id/v2015/persadia-rsi-sultan-agung/

RSISA TV. (2020). Channel Youtube Hospital Sultan Agung TV. Retrieved from https://www.youtube.com/watch?v=35YTDU2GbyQ 